 \\ Using Discourse to Restore Organisational Legitimacy: ‘CEO-speak' After \\ an Incident in a German Nuclear Power Plant \\ Beelitz, A.; Merkl-Davies, D.M.

\section{Journal of Business Ethics} \\ DOI: \\ $10.1007 / \mathrm{s} 10551-011-1065-9$ \\ Published: 01/01/2012
}

Peer reviewed version

Cyswllt i'r cyhoeddiad / Link to publication

Dyfyniad o'r fersiwn a gyhoeddwyd / Citation for published version (APA):

Beelitz, A., \& Merkl-Davies, D. M. (2012). Using Discourse to Restore Organisational Legitimacy: 'CEO-speak' After an Incident in a German Nuclear Power Plant. Journal of Business Ethics, 108(1), 101-120. https://doi.org/10.1007/s10551-011-1065-9

\footnotetext{
Hawliau Cyffredinol / General rights

Copyright and moral rights for the publications made accessible in the public portal are retained by the authors and/or other copyright owners and it is a condition of accessing publications that users recognise and abide by the legal requirements associated with these rights.

- Users may download and print one copy of any publication from the public portal for the purpose of private study or research.

- You may not further distribute the material or use it for any profit-making activity or commercial gain

- You may freely distribute the URL identifying the publication in the public portal ?

Take down policy

The final publication is available at Springer via http://link.springer.com/article/10.1007\%2Fs10551-011-1065-9

Take down policy

If you believe that this document breaches copyright please contact us providing details, and we will remove access to the work immediately and investigate your claim.
} 
Using discourse to restore organisational legitimacy:

'CEO-speak' after an incident in a German nuclear power plant

Annika Beelitz ${ }^{\mathrm{a}}$

and

Doris M. Merkl-Davies ${ }^{\mathrm{a}}$

${ }^{a}$ Bangor Business School, Bangor University, Bangor LL57 2DG, UK

Address for correspondence: Doris Merkl-Davies, Bangor Business School, Bangor University, Bangor, Gwynedd, LL57 2DG, UK. Tel.: 0044-(0)1248-382120; abs213@bangor.ac.uk. 


\title{
Using discourse to restore organisational legitimacy: 'CEO-speak' after an incident in a German nuclear power plant
}

\begin{abstract}
We analyse managerial discourse in corporate communication ('CEO-speak') during a six month period following a legitimacy-threatening event in the form of an incident in a German nuclear power plant. As discourses express specific stances expressed by a group of people who share particular beliefs and values, they constitute an important means of restoring organisational legitimacy when social rules and norms have been violated. Using an analytical framework based on legitimacy as a process of reciprocal sense-making and consisting of three levels of analysis which capture the relationship between text and context, we investigate the discourse used by CEOs in their initial and subsequent accounts of the incident. We find that CEOs aim to negotiate a resolution between their initial account and organisational audiences' incongruent interpretations of the event by adopting an ad hoc normative attitude to stakeholders. This manifests itself in the strategic use of the discourse of stakeholder engagement as a means of signalling change, yet maintaining the status quo. It suggests that CEOs strategically use discourse to manufacture organisational audiences' consent regarding the continued operation of the nuclear power plant affected by the incident. Our findings contribute to the critical corporate communication literature which regards corporate narrative reporting as a means of consolidating the private interests of corporations, rather than increasing transparency and accountability.
\end{abstract}

Keywords: Legitimacy, Impression Management, Nuclear Industry, Discourse, Stakeholder Management.

The authors acknowledge the helpful comments of the participants of the research seminar at the University of Exeter Business School on $1^{\text {st }}$ April 2011, the participants of the Irish Accounting \& Finance Association Conference at the University College Cork on 28 April 2011, Niamh Brennan from University College Dublin, and the two anonymous reviewers. 


\section{INTRODUCTION}

The nuclear industry's biggest challenge is "not one of technical or even cost difficulties, but of maintaining a veneer of political legitimacy” (Stoett, 2003, p. 99). This is particularly the case in Germany which is characterised by a strong anti-nuclear movement. The recent accident in the Fukushima nuclear power plant in Japan reignited the public debate on nuclear power in Germany. Wide-spread anti-nuclear protests forced the German government to revoke its plans to extend the life span of Germany's seventeen nuclear power plants by an average of twelve years. An incident in a German nuclear power plant thus constitutes an interesting context to examine the strategies adopted by management to restore organisational legitimacy during a public controversy.

Organisational legitimacy refers to "a generalized perception or assumption that the actions of an entity are desirable, proper, or appropriate within some socially constructed system of norms, values, beliefs, and definitions" (Suchman, 1995, p. 574). Legitimacy is considered vital for an organisation's survival, as it attracts resources and the continued support from its constituents (Ashforth and Gibbs, 1990). Corporate communication constitutes an important means for management to demonstrate that the organisation's practices are congruent with society's values, norms, and beliefs (Dowling and Pfeffer, 1975; Lindblom, 1994). In times of crisis or controversy, such as during financial scandals, environmental disasters, and major structural reorganisation, management uses corporate communication to restore organisational legitimacy by persuading audiences that the organisation is re-aligning its structures and procedures with social norms and rules (Elsbach, 2001).

\subsection{Motivation, objectives and contribution of the paper}

The aim of the paper is to unravel the role of managerial discourse in the construction of organisational legitimacy by Vattenfall, a Swedish state-owned energy company, after an incident in one of its nuclear power plants in Germany. The prior literature regards organisational legitimacy as static and unidirectional. The focus of analysis is on legitimacy construction at one particular point in time, for example by analysing the annual report following a specific crisis or controversy (e.g., Ogden and Clarke, 2005; Linsley and Kajüter, 2008). By contrast, we regard legitimacy as "achieved and maintained through social dialogue ... and reliant on organisational communication" 
(Tregidga et al. 2007, p. 5). Thus, our analysis focuses on the discursive negotiation of legitimacy between management and organisational audiences over time.

For this purpose, we develop an analytical framework based on Ginzel et al.'s (2004) concept of impression management as an interactive process between management and organisational audiences and Fairclough's (1995) approach to text analysis which links the micro analysis of texts to macro social discourses which they reflect and help constitute. Fairclough (1995) regards language and society as dialectally interrelated. He proposes a framework incorporating three levels of analysis, namely (1) micro-level (text), (2) meso-level (discourse practice context incorporating text production, reception and adaptation), and (3) macro-level (situational, institutional and societal context). Legitimacy construction is located at the discourse practice level and takes the form of a negotiation process between senior management and organisational audiences (Ginzel et al., 2004).

Using insights from Critical Discourse Analysis (CDA), the focus of our analysis is on the way discourse is used by senior management to persuade organisational audiences that the organisation has adopted violated social norms and values after a legitimacythreatening event. Discourses are specific ways of representing a particular aspect of social life (Fairclough, 2003) and can thus be used to control organisational audiences' impressions of the organisation (e.g., Amernic and Craig, 2007; Craig and Amernic, 2004a, 2006, 2008; Livesey et al. 2002a, 2002b). We focus on 'CEO-speak' (Amernic and Craig, 2006, 2007), i.e., the use of discourse by CEOs in speeches, statements during press conferences, interviews with the media, and CEO messages in corporate annual reports. The words of CEOs have 'clout' (Amernic and Craig, 2006, p. 4) in that they not only shape the perceptions of stakeholders and society, but also create ideology, thus impacting on the way the world is run (Amernic and Craig, 2006). This is particularly important in times of crisis, when CEOs are expected to assume rhetorical leadership (Amernic and Craig, 2006), such as during legitimacy-threatening events. We find that CEOs use discourse strategically as a means of signalling change, yet maintaining the status quo. Our findings contribute to the critical research on corporate narrative reporting by highlighting the way discourse is used in corporate communication to sustain relations of domination (Milne et al., 2009). 


\subsection{Structure of the paper}

The remainder of the paper comprises of five sections. First, we discuss the concept of organisational legitimacy, including strategies to (re)establish organisational legitimacy and the role of discourse in legitimacy construction. Then, we present our analytical framework which consists of three levels of analysis (text, discourse practice-context and macro-context) aimed at capturing the interrelationship between text and context. Third, we describe our data and sample. Fourth, we apply our analytical framework to the analysis of the discursive negotiation of legitimacy between management and organisational audiences following an incident in a German nuclear power plant and discuss the limitations of our analytical framework in a broader context. Finally, in the conclusion, we discuss our findings and contribution to the literature.

\section{ORGANISATIONAL LEGITIMACY}

As legitimacy is a social construct in the sense that it is subjectively perceived and ascribed to an organisation's actions and outcomes (Palazzo and Scherer, 2006), it is predominantly analysed from a symbolic-interpretive perspective (Hatch and Cunliffe, 2006). The prior literature conceptualises organisational legitimacy from two different perspectives. Adopting an agency focus, the strategic perspective regards legitimacy as an operational resource which can be employed in the pursuit of organisational goals (Suchman, 1995; Palazzo and Scherer, 2006). Adopting a structure focus, the institutional perspective views legitimacy as the collective awareness and recognition of an organisation's practices as acceptable, appropriate, and desirable (Suchman, 1995). From this perspective legitimacy "resides in people's minds" (Breton and Coté, 2006, p. 512) and is granted by organisational audiences when they perceive the organisation's practices to be congruent with social rules, norms, and values. The perspective adopted impacts on the definition of organisational legitimacy, the viewpoint (either managers "looking out" or organisational audiences "looking in", Suchman, 1995, p. 577), the choice of theories used, the focus of analysis, and the research design. The strategic perspective foregrounds the role of management in the construction of legitimacy by focusing on strategies adopted to restore organisational legitimacy after a crisis or conflict. By contrast, the institutional perspective is concerned with the role of organisational audiences in legitimacy construction by focusing on the way the organisation is portrayed in the media. See Table 1 for an overview of the two perspectives. 
Table 1: Contrasting the strategic and institutional perspective on organisational legitimacy

\begin{tabular}{|c|c|c|}
\hline & Strategic perspective & Institutional perspective \\
\hline $\begin{array}{l}\text { Definition of } \\
\text { legitimacy }\end{array}$ & $\begin{array}{l}\text { Managers 'looking out': } \\
\text { Managerial attempt to demonstrate } \\
\text { that organisational practices are } \\
\text { congruent with society's norms } \\
\text { values, and beliefs. }\end{array}$ & $\begin{array}{l}\text { Organisational audiences 'looking in': } \\
\text { Perception of organisational audiences that } \\
\text { organisational practices are congruent } \\
\text { with social norms, values and beliefs }\end{array}$ \\
\hline $\begin{array}{l}\text { Assumption of } \\
\text { human nature }\end{array}$ & $\begin{array}{l}\text { Agency focus } \\
\text { Active: } \\
\text { - Legitimacy as an organisational } \\
\text { resource } \\
\text { - Legitimacy is controlled by } \\
\text { management } \\
\text { - Legitimacy can be manipulated }\end{array}$ & 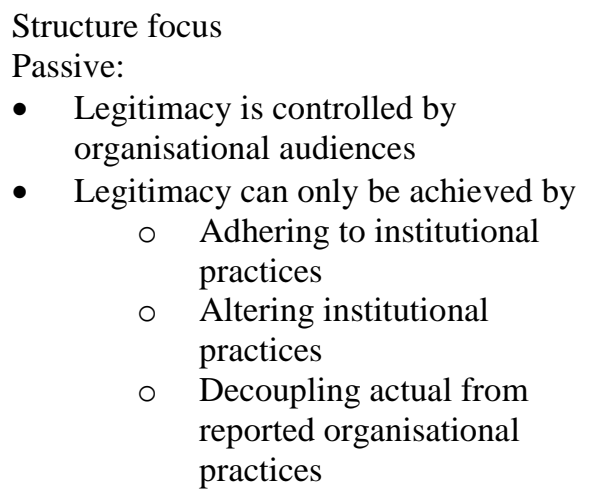 \\
\hline $\begin{array}{l}\text { Theoretical } \\
\text { approaches }\end{array}$ & $\begin{array}{ll}\text { - } & \text { Stakeholder theory } \\
\text { - } & \text { Legitimacy theory }\end{array}$ & $\begin{array}{l}\text { - } \quad \text { Legitimacy theory } \\
\text { - } \quad \text { Institutional theory }\end{array}$ \\
\hline $\begin{array}{l}\text { Focus of } \\
\text { analysis }\end{array}$ & $\begin{array}{ll}\text { - } & \text { Substantive management } \\
\text { - } & \text { Symbolic management }\end{array}$ & $\begin{array}{ll}\text { - } & \text { Isomorphism } \\
\text { - } & \text { Decoupling }\end{array}$ \\
\hline Research design & - Legitimacy-threatening event & - $\quad$ Print media coverage of organisation \\
\hline
\end{tabular}

Management is assumed to use corporate communication as a means of managing organisational legitimacy. As legitimacy is not directly observable, researchers infer legitimating processes and effects by focusing on events which violate social norms, values, and beliefs and thus pose obvious legitimacy threats to organisations, such as restructuring and reorganisation (Arndt and Bigelow, 2000), privatization and demutualization (Craig and Amernic, 2004a, 2006, 2008; Odgen and Clarke, 2005), environmental disasters (Hooghiemstra, 2000), and corporate scandals (e.g., Elsbach, 1994; Craig and Amernic, 2004b; Breton and Coté, 2006; Linsley and Kajüter, 2008; Lightstone and Driscoll, 2008; O'Keefe and Conway, 2008). The focus of analysis is on the strategic use of corporate narrative documents as a means of managing audiences' perceptions of the event, thus restoring legitimacy.

\subsection{Strategies to (re)establish legitimacy}


Prior research has identified a variety of strategies used by management to (re)establish legitimacy. The strategies can be classified according to the underlying concept of legitimacy (i.e., either strategic or institutional) and whether they entail any real changes in organisational practices or values (i.e., substantive management and isomorphism) or, alternatively, merely manipulate audiences' perceptions of organisational practices and values (i.e., symbolic management and decoupling). See Figure 1 for an overview. Adopting a strategic perspective, Ashforth and Gibbs (1990) differentiate between substantive and symbolic management. Substantive management entails a real change in organisational processes or institutionalised practices. As legitimacy threats arise from an organisation failing to act in a manner which society considers normatively appropriate (e.g., by failing to meet society's expectations with respect to product safety, animal welfare, or human rights), restoring legitimacy involves demonstrating that the organisation has adopted violated values. By contrast, symbolic management entails implementing strategies which make the organisation appear to respond to stakeholder concerns or appear to be congruent with society's norms and expectations. Firms facing a major legitimacy threat engage in symbolic management by separating the negative event (e.g., fraud, scandal, or product safety issue) from the organisation as a whole by providing normalising accounts and by engaging in strategic restructuring. The purpose of normalising accounts and strategic restructuring is to construct a 'firewall' between audience assessments of the legitimacy-threatening event and the organisation as a whole. Normalising accounts entail the use of verbal remedial strategies, such as excuses, apologies, and justifications. Strategic restructuring entails "selectively confess[ing] that limited aspects of its operations were flawed" (Suchman, 199, p. 598) and then decisively and visibly remedying them by introducing small and narrowly tailored changes. Two types of strategic restructuring have been identified by the prior literature, namely (1) creating monitors and watchdogs and (2) disassociation. Disassociation entails symbolically distancing the organisation from negative influences. For example, executive replacement allows the organisation to dissociate itself from a legitimacy-threatening event by putting the blame on individual members of the organisation. Organisations can also dissociate themselves from de-legitimated procedures and structures. Adopting an institutional perspective, DiMaggio and Powell (1983) argue that organisations respond to social and institutional pressures and expectations by means of either isomorphism or decoupling. Depending on the nature of the legitimacy- 
threatening event, management may respond by either altering organisational structures and processes so that they are in line with social and institutional norms and rules or by emphasising institutional conformity (isomorphism). Alternatively, organisational structures and processes may just appear to conform to social and institutional norms and rules. This constitutes decoupling.

Figure 1: Strategies to (re)establish organisational legitimacy

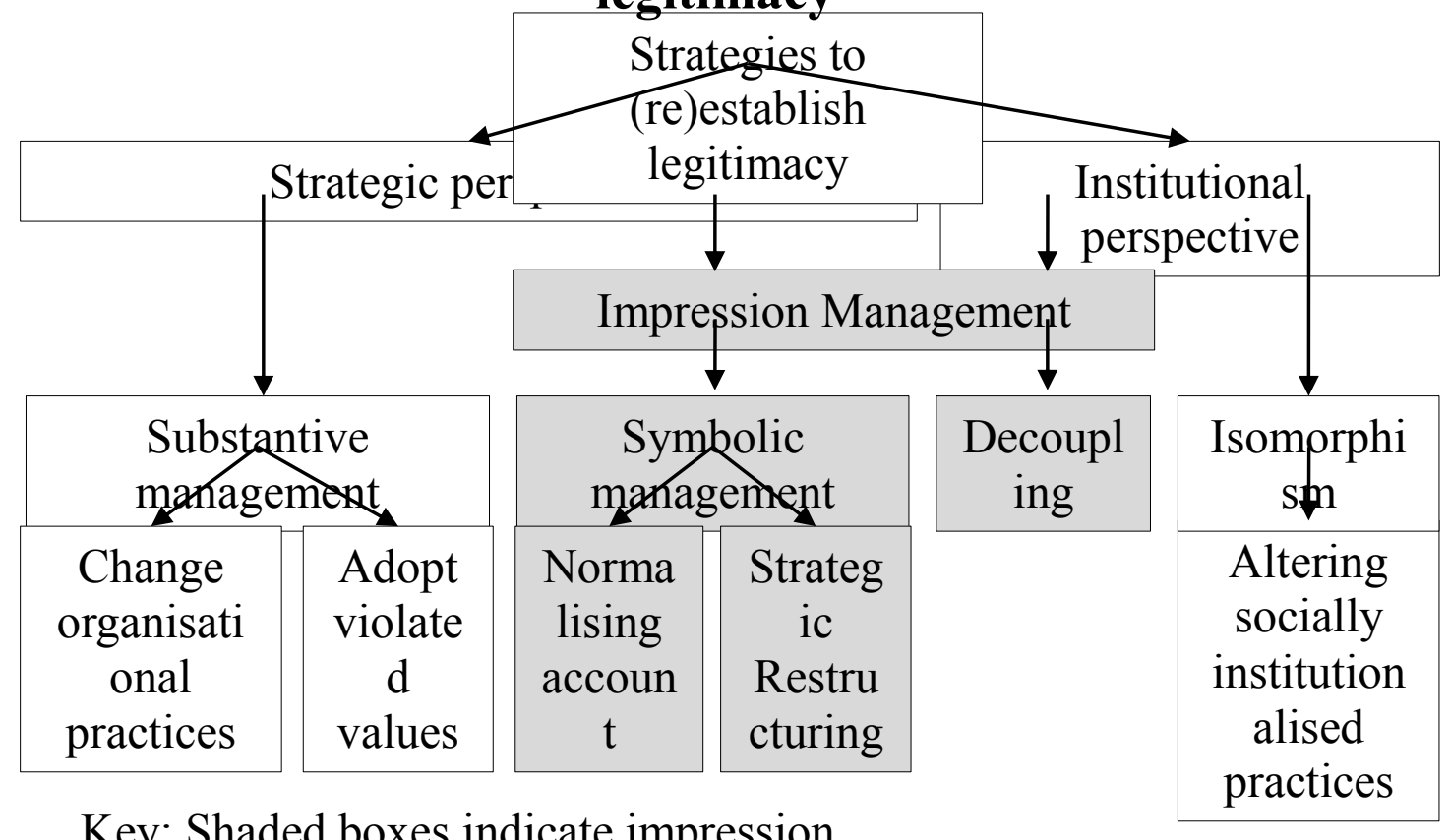

Key: Shaded boxes indicate impression management strategies

Symbolic management and decoupling constitute impression management in the sense that they entail shaping an audience's impression of a person, an object, an event, or an idea (Schlenker, 1980). The concept of impression management originates in social psychology and can be traced back to the work of Goffman (1959). Using a dramaturgical metaphor, Goffman (1959) explains impression management as the performance of self vis-à-vis an audience. Impression management is used to establish, maintain, or repair organisational legitimacy by influencing organisational audiences' impressions of organisational outcomes or events so that they are perceived to be congruent with social norms, values, and beliefs (see, for example, Elsbach, 1994; Hooghiemstra, 2000; Breton and Coté, 2006; Linsley and Kajüter, 2008). We argue that management may use impression management to restore organisational legitimacy after a crisis or controversy by persuading organisational audiences that the organisation has adopted violated social norms and values (Merkl-Davies and Brennan, 2011). 


\subsection{The role of discourse in legitimacy construction}

We draw on Critical Discourse Analysis (CDA) for insights on the role of discourse in legitimacy construction. CDA is a form of social research focusing on language which is regarded as dialectically interconnected with other elements of social life (Fairclough, 2003). Focusing on the dialectic relationship between language and society, CDA addresses how the content and the linguistic features of texts influence and are, in turn, influenced by the contexts of text production, distribution, reception and adaptation, and by the wider socio-economic context in which texts are embedded. CDA is critical in the sense that it studies "the way social power abuse, dominance, and inequality are enacted, reproduced and resisted by text ... in the social and political context" (Van Dijk, 2001, p. 253). Discourses are specific ways of construing particular aspects of social life (e.g., different discourses on immigration or on climate change) which can be identified with different perspectives of various groups of social actors (Fairclough, 2009). Discourses thus represent particular perspectives on the social world and can be differentiated by specific stances expressed by a group of people who share specific beliefs and values. As legitimacy is a function of the organisation acting according to the norms, values, and beliefs of society, the adoption of violated values constitutes a crucial strategy for restoring organisational legitimacy.

The prior accounting literature focuses on the strategic use of specific discourses (e.g., the economic discourse of efficiency and effectiveness) to convince organisational audiences of the legitimacy, necessity, and validity of potentially controversial actions and decisions, such as privatisation (Craig and Amernic, 2004b, 2006, 2008). Discourses constitute part of the resources people use to relate to one another, i.e., either keeping separate from one another, cooperating or competing with one another, or dominating one another (Fairclough, 2003, p. 124). They may thus be deployed strategically to redefine an organisation's relationship with its stakeholders during a public controversy or crisis. We focus on the strategic use of discourse as a means of resolving a conflict between the organisation and its audiences by means of signalling that it has realigned its norms and values with that of society. This constitutes an ethical issue as it entails influencing organisational audiences' ideas and managing their perceptions as a means of manufacturing their consent. 


\section{FRAMEWORK OF ANALYSIS}

We adopt an abductive approach. This entails developing our analytical framework and categories of text analysis in accordance with our research questions by means of "oscillating between theory and data analysis in retroductive ways" (Wodak and Meyer, 2009, p. 19). Our analytical framework is based on Fairclough $(1995,2003)$ and consists of the three levels of analysis (text, discourse practice-context and macrocontext) which capture the interrelationship between text and context. The analytical categories relevant for text analysis emerge during an iterative process of going back and forth between the theoretical concepts developed in Sections 2 and 3 of the paper and the empirical data described in Section 4.2.

\subsection{Levels of analysis: Text and context}

Fairclough $(1995,2003)$ regards the roles, relations and identities of discourse participants within a discourse community to be constituted and negotiated by means of spoken and written texts. As such, texts are embedded in wider socio-economic and political contexts. His analytical framework addresses how the content and the linguistic features of texts influence, and are, in turn influenced, by the contexts of text production, distribution, reception and adaptation, and by the wider socio-economic context in which texts are embedded (Fairclough, 1995, 2003). Fairclough (1995) operationalises this dialectic relationship between language and society in a framework consisting of three levels of analysis, namely (1) the text itself (micro-level), (2) the context of producing, distributing, receiving and possibly adapting texts within a discourse community (meso-level), and (3) the dynamic socio-economic and political context in which the discourse community can be located (macro-level). In this framework corporate communication can be regarded as a micro-process through which management aims to "control the way in which the corporate story is interpreted" (Crowther et al., 2006, p. 199). The three interrelated levels of analysis, including our analytical categories, are illustrated in Figure 2. 
Figure 2: Levels of analysis: Text and context

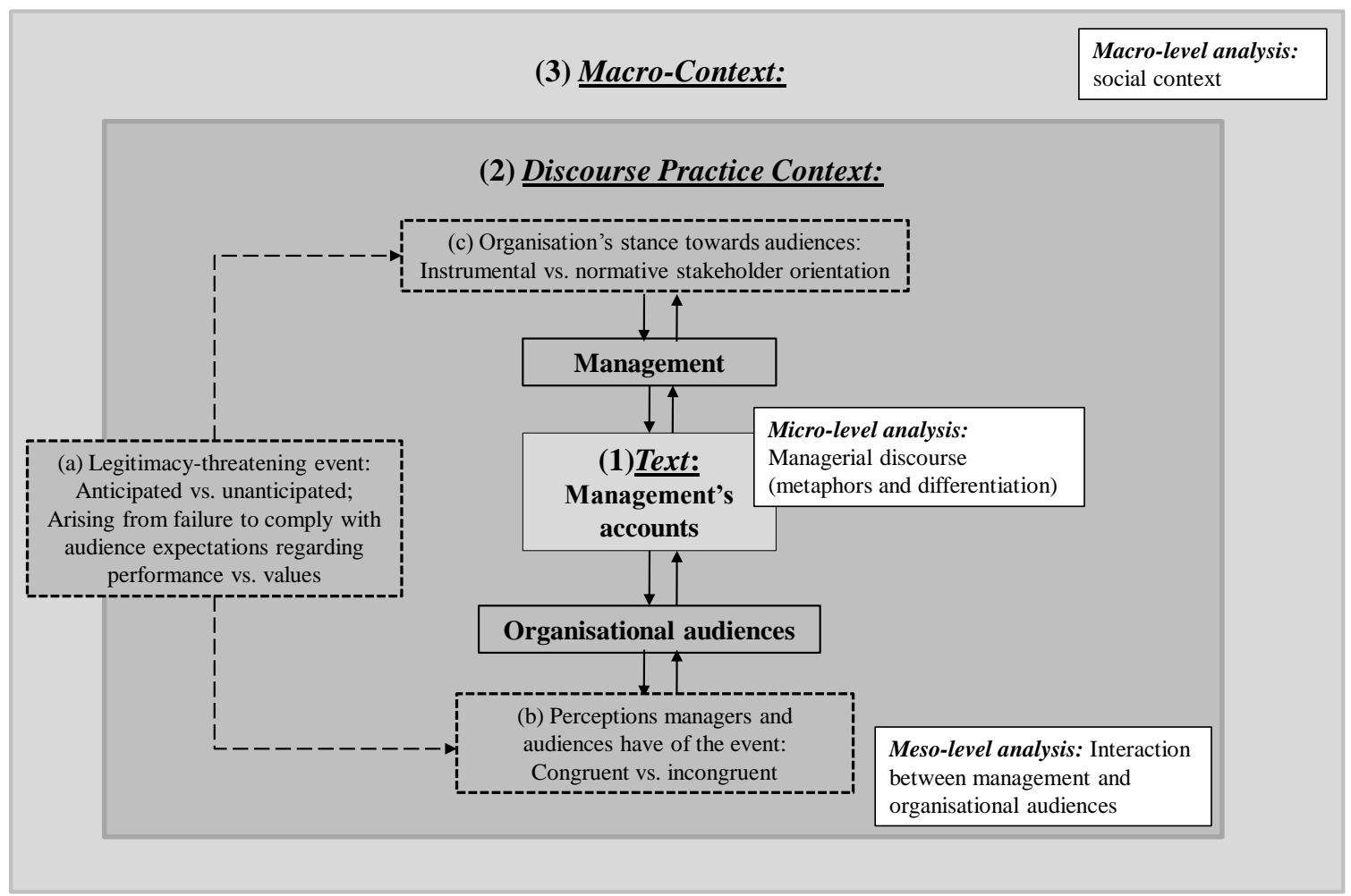

Key: Adapted from Fairclough, 1995 and Ginzel et al., 2004. Shaded boxes refer to factors impacting on legitimacy construction.

\subsection{Macro-level analysis}

Macro-level analysis involves taking the wider social formation into account to interpret the findings of the text analysis. The aim of the analysis is to explain why social actors, events and organisations are represented and arguments are constructed in a specific way. Depending on the text(s) in question, the focus may be on historical, economic, political, or cultural formations or on a combination of them. The focus of analysis is on details of the social formation (e.g., the roles allocated to people), and on changes in the social formation and reasons for these changes. In our case, the macrocontext is concerned with the legitimacy of the nuclear industry in Germany.

\subsection{Meso-level analysis}

Meso-level analysis explains the reasons for the presence of specific discourses in the texts under investigation by recourse to the discourse practice context which includes the production, distribution, reception and possible adaptation of texts. An analysis of the discourse practice context focuses on the roles of members of a discourse community and the relationships between them. In the case of corporate narrative 
documents this entails analysing the relationship between managers and stakeholders, including regulatory agencies, politicians, and intermediaries, such as the media. Both for text producers and recipients discourse practice also involves issues of unequal discourse access due to asymmetrical power between participants.

As we conceptualise legitimacy as being discursively constructed in the interaction between management and organisational audiences over time (Ginzel et al., 2004), it is part of the discourse practice context. Figure 2 illustrates the factors impacting on legitimacy construction. The negotiation of legitimacy consists of at least three phases, namely (i) the account generation process during which management provides an interpretation of an event, (ii) the reaction of organizational audiences to management's interpretation of the event, and (iii) a subsequent account generation process during which management attempts to negotiate a resolution between its initial account and the interpretation by organizational audiences. The negotiation process constitutes a struggle over meaning with both parties aiming to have their definition of reality accepted (Suchman, 1995, p. 597).

A legitimacy-threatening event prompts management to provide an account which constitutes management's interpretation of an event. Accounts are verbal explanations or "'verbal remedial strategies' that 'provide explanations for problematic behaviours designed to rectify a predicament"' (Gonzales et al., 1990, p. 610; cited in Ginzel et al. 2004, p. 231). For this purpose, management may engage in impression management in order to influence organisational audiences' perceptions of the event. A managerial account may be in the form of a press release, a CEO statement during a press conference, or a media interview with a company executive. Depending on whether management's and organisational audiences' interpretations of the event are congruent or incongruent, the initial managerial account is either accepted or rejected. If it is rejected, management provides a subsequent account which aims to resolve the conflicting interpretations of the event, thus restoring organisational legitimacy.

We regard the interaction between management and organisational audiences as determined by a variety of factors, including (a) the nature of the legitimacy-threatening event (i.e., anticipated/unanticipated and arising from managerial failure to comply with audience expectations regarding performance/values), (b) the perceptions 
management and organisational audiences have of the event (i.e., congruent/incongruent), and (c) the organisation's stance towards its audiences (i.e., instrumental/normative stakeholder orientation). The legitimacy-threatening event can be either anticipated or unanticipated. Unanticipated events "are especially difficult for top managers to cope with when they immediately place the organization's image or reputation in doubt" (Ginzel et al., 2004, p. 227). Elsbach (2001, p. 405) argues that legitimacy threats caused by unanticipated events can be successfully restored by using "technical and logical arguments and ... communicated through technical jargon". By contrast, legitimacy threats caused by anticipated events can be successfully restored by taking the views of organisational audiences into consideration "backed up by references to widely accepted social norms ... communicated through common language" (Elsbach, 2000, p. 405). Legitimacy-threatening events either arise from the organisation's failure to comply with audience expectations of organisational performance or involve a violation of values (Ashforth and Gibbs, 1990). Performancerelated legitimacy threats are due to the organisation's failure to meet its goals (e.g., through poor service), whereas value-related legitimacy threats call the organisation's mission and thus its essence into question.

The stance adopted by the organisation towards its stakeholders impacts on strategies chosen by management to restore legitimacy. The literature suggests that organisations either adopt an instrumental or a normative stance towards their stakeholders. An instrumental stakeholder orientation regards stakeholders as a means an end, i.e., to create economic (shareholder) value. By contrast, a normative stakeholder orientation recognises stakeholders as means in themselves and aims to achieve social and environmental, as well as economic value. An organisation's stance towards its stakeholders impacts on five aspects of corporate social responsibility, namely (1) organisational purpose, (2) stakeholder identification and salience, (3) stakeholder management, (4) performance metrics, and (5) the boundary between the organisation and its stakeholders (O'Higgins, 2010). Organisational purpose relates to the way the organisation conceives of its purpose, i.e., for whose benefit the organisation exists and the role (if any) of stakeholders in achieving this purpose. Stakeholder identification and salience refer to the different criteria employed for deciding who is a stakeholder and their importance in achieving the organisational purpose. Stakeholder management relates to the different approaches adopted towards strategic analysis with respect to 
stakeholders. Performance metrics refer to the performance measures used to assess organisational success in performance according to the organisation' purpose and stakeholder management practices. Finally, the boundary between the organisation and its stakeholder relates to how the organisation defines itself in relation to its environment (O’Higgins, 2010).

\subsection{Micro-level analysis}

Micro-level text analysis focuses on the specific linguistic features which are of particular importance for the text(s) under investigation. These are dependent on the research objective, the genre of the text(s), and the audience it is aimed at. We focus on the discourses used by Vattenfall's CEOs ('CEO-speak') to construct organisational legitimacy after an incident in one of their nuclear power plants in Germany. This entails identifying the aspect of the social world (theme or topic) represented in the text(s) under investigation and the particular point of view (perspective) from which it is represented (Fairclough, 2003). The most obvious distinguishing feature of discourses is vocabulary, as discourses lexicalise and thus structure the social world in particular ways. Discourses thus manifest themselves in keywords, metaphors and differentiation (i.e., binary opposites) (Fairclough, 2003). Metaphors entail "understanding and experiencing one kind of thing in terms of another" (Lakoff and Johnson, 1980, p. 5). They are resources for producing distinct representations of the world. Conversely, the particular combination of different metaphors differentiates discourses (Fairclough, 2003). Differentiation refers to the fact that people understand the world in terms of significant pairings, contrasts, or dualities, such as up-down, mind-body, public-private, etc. which are often seen "in contradiction to each other, frequently with one term assuming dominance" (Llewellyn, 2003, p. 670). Differentiation and metaphor are used to set up specific value systems and associated assumptions (Fairclough, 2003). Table 2 summarises the two dimensions of discourses and corresponding semantic and rhetorical devices. 


\section{Table 2: Elements of discourse}

Dimensions of discourses Definition of dimensions

a. Aspect of the social world

b. Particular point of view
Theme/topic

(e.g., immigration)

Perspective (e.g., right-wing)
Semantic \& rhetorical devices

Keywords (e.g., foreigners, asylum seekers)

Metaphors, differentiation (e.g., overrun, hard-working families vs. illegal immigrants)

Text analysis entails first identifying the keywords which are indicative of the themes or topics represented in the text and then the metaphors and binary opposites which signify the particular stance adopted by the author either towards the content or the readers of the text (Hyland, 1998). The predominance of keywords, such as 'stakeholders' (e.g., documents 4 and 6), 'the general public' (e.g., documents 2, 4, and 9), and 'customers' (e.g., documents 3, 4, and 8) suggests that the predominant theme of all nine CEO texts is Vattenfall's stance towards its organisational audiences. Thus, the focus of analysis is on the discourse of stakeholder orientation. We compare the metaphors and differentiation used by Vattenfall's CEOs in their initial and subsequent accounts of the incident at the Krümmel nuclear power plant. We find the initial account to be characterised by metaphors and differentiation associated with technocratic discourse emphasising facts and figures and rule compliance. By contrast, subsequent accounts are characterised by metaphors and differentiation indicative of the discourse of stakeholder engagement. Technocratic discourse draws on scientific and technological discourse and shares lexical features with managerialism and the military (McKenna and Graham, 2000). By claiming rational objectivity and promoting action based on reason and fact, technocratic discourse communicates instrumental rationality (Elsbach, 2001). Instrumental rationality is a rationality of means which involves "applying appropriate reason to choose the best possible means to attain one's ends" (Tomer, 2008, p. 1704). By contrast, the discourse of stakeholder engagement emphasises dialogue, understanding, and sharing. It promotes action based on emotion (Greenwood, 2007) and communicates understanding and consideration of stakeholders' views (Elsbach, 2001). This involves substantive rationality. Substantive rationality is concerned with ideals, goals and ends which are pursued for their own sake, such as equality, justice, freedom, respect for the environment (Weber, 1968). 
Substantive rationality is a rationality of ends which involves applying appropriate reason to achieve these ends.

The technocratic discourse and the discourse of stakeholder engagement are thus diametrically opposed to each other in terms of the stance adopted by the organisation towards its stakeholders (i.e., instrumental versus normative stakeholder orientation), which, in turn, is due to their different underlying concepts of rationality (i.e., instrumental vs. substantive). The technocratic discourse and the discourse of stakeholder engagement (perspectives) are juxtaposed by means of a series of metaphors and significant pairings which relate to the five aspects of corporate social responsibility (sub-themes) outlined in Section 3.3, namely (1) organisational purpose, (2) stakeholder identification and salience, (3) stakeholder management, (4) performance metrics, and (5) the boundary between the organisation and its stakeholders (see Figure 3). The metaphors and differentiation associated with each of the five aspects of corporate social responsibility are drawn from the nine CEO texts which form the basis of our micro-level analysis. Appendix 1 illustrates the empirical application of our categories of analysis by means of quotes. 
Figure 3: Micro-level analysis: Analysing the managerial discourse in Vattenfall's CEO texts

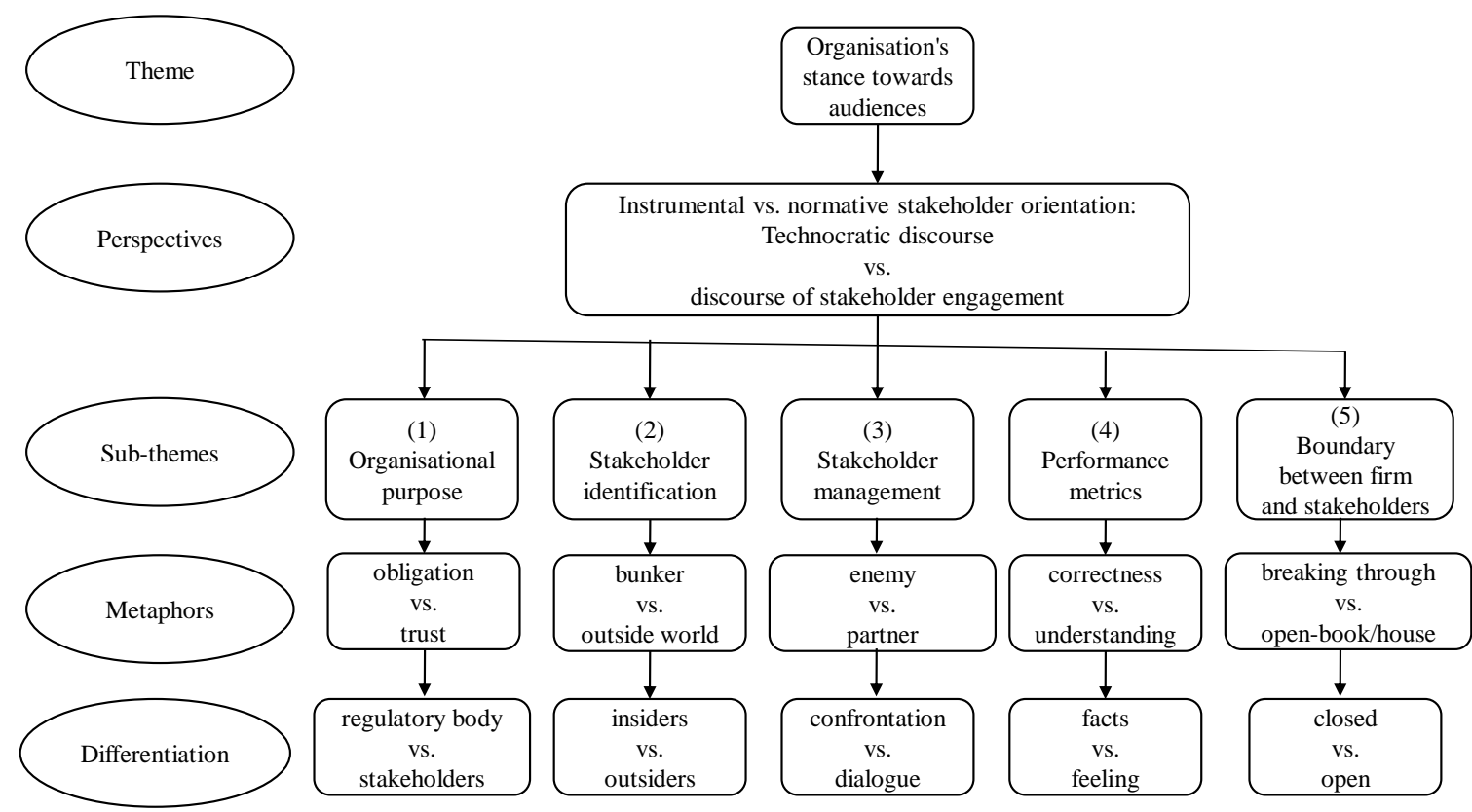

\section{DATA AND SAMPLE SELECTION}

We analyse the attempt by Vattenfall, a Swedish state-owned energy company, to restore organisational legitimacy after an incident in Krümmel, one of its nuclear power plants in Germany. Krümmel is jointly operated by Vattenfall Europe Nuclear Energy $\mathrm{GmbH}$ (an associated company of Vattenfall Europe AG, the German subsidiary of the Swedish parent company, Vattenfall AB) and E.ON.

\subsection{Data}

We collect all corporate narrative documents relating to the incident issued during a six-month period between the incident and the financial year-end on $31^{\text {st }}$ December 2007. ${ }^{1}$ We use the keyword 'Krümmel' and the specified time period to search the news archives of web pages of the parent company, Vattenfall AB (vattenfall.com), and the German subsidiary, Vattenfall Europe AG (vattenfall.de). We identify 29 documents. They include press releases, interim reports, the annual report, the social corporate

\footnotetext{
1 The financial year-end is on 31 December 2007. The annual report and the Corporate Social Responsibility Report are published on 28 March 2008 and are included in our analysis.
} 
responsibility report, statements and speeches by company executives during press conferences, and a media interview. The documents are either in English or in German. Some English-language documents are word-for-word translations of German documents. When the German-language and English language documents are congruent, the English version is used. German documents without English-language equivalents are translated by the authors.

\subsection{Sample selection}

Our sample consists of nine CEO texts which are either 'authored' by the CEO of Vattenfall's German subsidiary (Vattenfall Europe AG) or by the CEO of the Swedish parent company (Vattenfall $\mathrm{AB}$ ) during the period of observation. ${ }^{2}$ The remaining documents are used for the meso-level analysis to provide insights on the interaction between management and organisational audiences. In the micro-level analysis we focus on 'CEO-speak' in the initial and subsequent accounts of the incident (i.e., the discourses used by Vattenfall's CEOs). As 'the social face of the organisation' (Brennan and Conroy, 2010, p. 7) the CEO is the organisational actor primarily in charge of legitimacy construction. By directly interacting with organisational audiences, particularly the media, and by means of press conferences and interviews, the CEO controls the way organisational actions and outcomes are interpreted. CEOs choose their words carefully and deliberately, with strategic purposes in mind (Amernic and Craig, 2006).

Table 3 lists the nine CEO texts which make up our sample by date, type of document, 'author', and source, including source language, and approximate length. The sample comprises one document by Klaus Rauscher, the CEO of Vattenfall Europe AG, the German subsidiary, at the time of the incident, two documents by Hans-Jürgen Crammer, who replaced Klaus Rauscher as the CEO of the German subsidiary on 18 July 2007, five documents by Lars G. Josefsson, the CEO of Vattenfall AB, the Swedish

\footnotetext{
2 The nine CEO texts are 'authored by four different CEOs. Goffman (1981) differentiates between (1) the principal, whose position the text reflects, (2) the author, who performs the writing task, and (3) the animator, who articulates the text. In our case, it is difficult to know whether Vattenfall's CEOs are authors in the Goffmanian (1981) sense. However, they can be considered both principals and animators of the texts under investigation. However, discourses, which are the focus of analysis in this paper, represent aspects of the social world from a particular perspective and are thus concerned with the views of the principal, rather than that of the author or animator.
} 
parent company, and one document by Per-Olof Waessman, Vattenfall AB's Chief Nuclear Officer. The first document by Klaus Rauscher constitutes the initial account provided by a CEO. It is a reinforcement of the initial account provided by management by means of press releases (see Figure 5). The remaining eight texts are subsequent accounts during which CEOs aim to negotiate a resolution between their initial account and incongruent interpretations by organisational audiences.

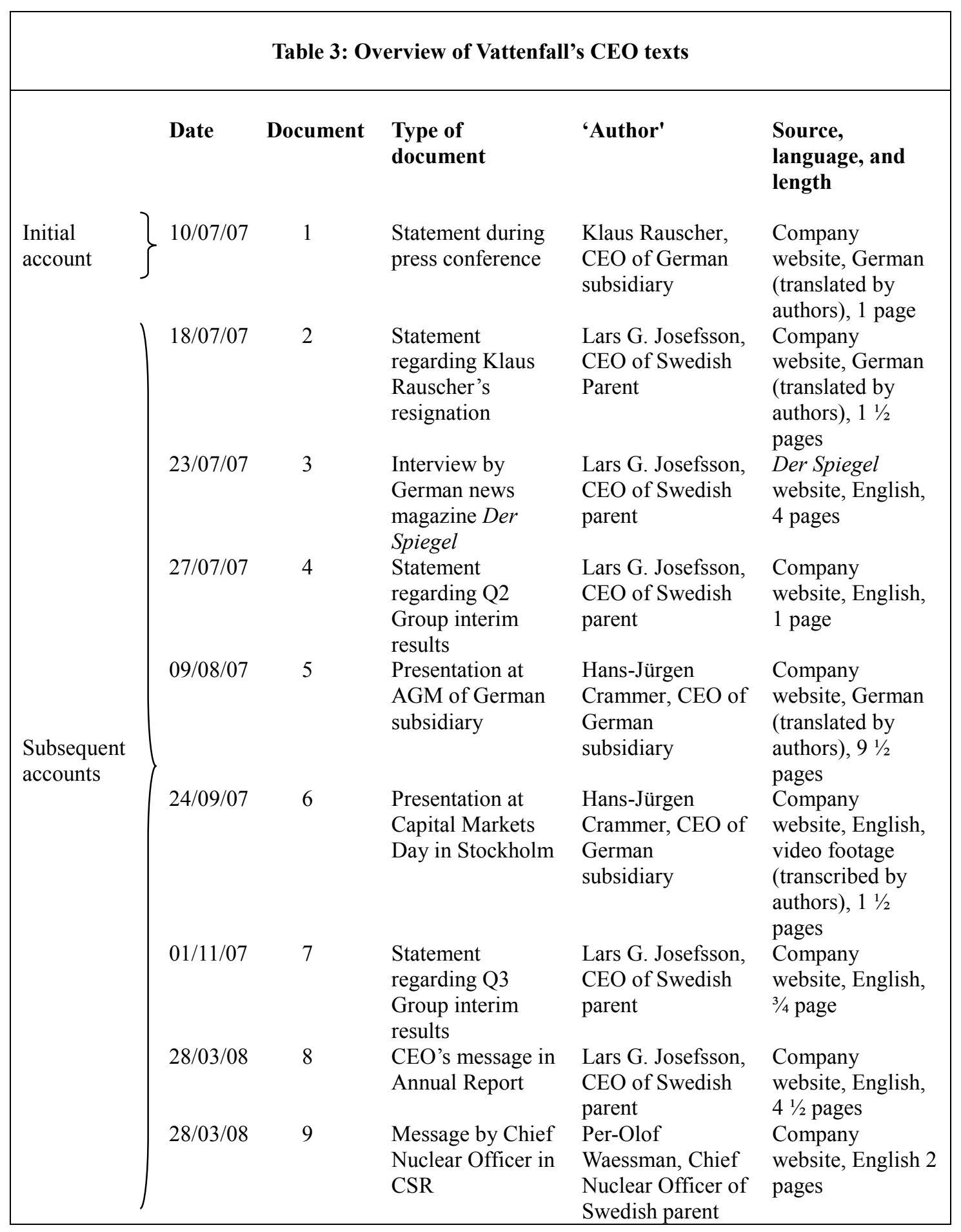




\section{FINDINGS}

We apply the analytical framework and the categories of analysis developed in Section 3 to analyse the negotiation of organisational legitimacy between Vattenfall's CEOs and organisational audiences following an incident in the Krümmel nuclear power plant.

\subsection{Background information}

Vattenfall, a Swedish state-owned energy company, has been operating in Germany since 2002 when Germany liberalised its energy market (Schulz and Wehmeier, 2010). Vattenfall runs three of the seventeen nuclear power plants in Germany, namely Brunsbüttel, Krümmel, and Brokdorf. Krümmel is situated on the river Elbe, $30 \mathrm{~km}$ south-east of Hamburg in the Federal Land of Schleswig-Holstein. It has been generating nuclear power since 1983. On the $28^{\text {th }}$ of June 2007 a fire broke out in a transformer building in Krümmel. The plant was shut down automatically and the incident was rated zero on the International Nuclear Event Scale (INES) which constitutes an event without safety significance. ${ }^{3}$ However, it resulted in a public controversy regarding the nuclear safety of Krümmel and the future of nuclear power in Germany. At the time of the incident Krümmel had a remaining lifespan of ten years.

\subsection{Macro-level analysis}

Nuclear energy is a contentious issue in Germany (Roose, 2010). The German antinuclear movement originates in the late 1960s when the first nuclear power plants were constructed to meet increasing demand for cheap energy. The initial opposition to nuclear power was due to its association with nuclear weapons during the Cold War era. There were few anti-nuclear protests in the 1960s. The anti-nuclear movement gained strength over time, with the number of demonstrations and number of people taking part rising throughout the 1970s and 1980s. It reached its peak in 1986 as a result of the nuclear incident at the Ukrainian nuclear power plant in Chernobyl. By then, the

\footnotetext{
${ }^{3}$ INES was introduced by the International Atomic Energy Agency (IAEA) in the 1990s. It is used for facilitating fast communication to the media and the public regarding the safety significance of events at any nuclear installation associated with the civil nuclear industry, including events involving the use of radiation sources and the transport of radioactive materials. Events are classified on the scale at seven levels. Events without safety significance are classified below scale at level 0 . For comparison, the accident at Three Mile Island near Harrisburg, Pennsylvania was rated 5 on the INES scale and Chernobyl was rated 7 on the INES scale (Borglin et al., 2008).
} 
anti-nuclear movement had gained political power due its sheer size, and protests often involved clashes between the protesters and the police. After decreasing protests in the early 1990s, the anti-nuclear movement was mobilised again in the late 1990s by the issue of the transportation and storage of nuclear waste. The coalition government of the Social Democratic Party (SPD) and the Alliance '90/The Greens that was formed in the 1998 election represented a turning point in the nuclear debate in Germany, because it was in favour of a nuclear phase-out. In 2002, following a long-drawn out political debate and lengthy negotiations between the Government and nuclear power operators, the German Parliament passed an Act on the structured phase-out of nuclear power by 2021. In 2007, after a change of government, politicians from the conservative Christian Democratic Union (CDU), including Chancellor Angela Merkel, argued for a delay of the nuclear phase out due to growing concerns about the reliability of Russian energy supplies to Western Europe (Deutsche Welle). The incident in Krümmel thus occurred at a political turning point with regarding the future of nuclear power in Germany. It refuelled the public debate on the safety of nuclear power, with environmental organisations demanding a quick nuclear phase-out across Germany (General-Anzeiger, 2007, June 30). Angela Merkel took position in this debate by making the following statement:

I am of the opinion that for safe nuclear reactors the limits imposed on their operating lives is a problem. But the prerequisite is, of course, that there is trust. And that everything demanded by the regulations is complied with (Der Spiegel, 2007, July 11).

Three days after the incident approximately one hundred protestors assembled at Krümmel to demand the plant's shut-down. What is more, Greenpeace, one of Vattenfall's harshest critics, stationed its boat 'Beluga II' on the river Elbe close to the plant (Die Welt, 2007, July 2). ${ }^{4}$

The anti-nuclear movement has broad public support in Germany. In 1978/79, twelve percent of the population opposed nuclear power (Roose, 2010). In 1996, this number rose to over 40 percent. In 2006 an opinion poll carried out by the German Forsa

\footnotetext{
${ }^{4}$ On its German website Greenpeace aims to expose Vattenfall's campaign entitled 'Klimaunterschrift' (signatures for the environment) as greenwashing. Vattenfall launches this campaign in 2007 in the aftermath of the incident at Krümmel as a means of restoring organisational legitimacy. Vattenfall portrays the campaign as a change in structures and processes and institutional conformity in terms of social and environmental responsibility (isomorphism), whereas Greenpeace argues that it constitutes espousing socially acceptable goals (decoupling).
} 
Institute for the Ministry of Environment found 71 percent of the population perceive nuclear energy to be an unacceptable risk and 51 percent regard nuclear energy as a high or very high risk (Bundesministerium für Umwelt, Naturschutz und Reaktorsicherheit, 2006). This suggests that an incident in a German nuclear power plant constitutes a legitimacy-threatening event.

Vattenfall's legitimacy was already damaged due to prior incidents in other nuclear power plants both in Germany and in Sweden. The incident in Krümmel resulted in heavy criticism of Vattenfall's management by the German media, politicians, and environmental groups, thus further damaging its legitimacy. The incident also triggered an intense political debate on the future of nuclear power in Germany, with the centreleft Social Democratic Party (SPD) arguing for an acceleration of the phase-out of nuclear power and the conservative Christian Democratic Union (CDU) arguing against it (Berliner Zeitung, 2007, June 30). Thus, the incident threatened the survival of the entire nuclear energy industry in Germany. Figure 4 provides an overview of events.

\section{Figure 4: Key events}

\begin{tabular}{|c|c|c|}
\hline \multirow{3}{*}{$\begin{array}{l}\text { Legitimacy threat } 1 \text { : } \\
\text { Safety crisis: } \\
\text { Violation of performance } \\
\text { (technical problem) }\end{array}$} & $28 / 06 / 07$ & Fire breaks out in transformer building at Krümmel nuclear power station near Hamburg. \\
\hline & $30 / 06 / 07$ & Greenpeace stages protest with ship Beluga II on Elbe in front of Krümmel. \\
\hline & 03/07/07 & Supervisory authority informs public of abnormalities during the shutdown at Krümmel. \\
\hline \multirow{9}{*}{$\begin{array}{l}\text { Legitimacy threat 2: } \\
\text { Confidence crisis: } \\
\text { Violation of values } \\
\text { (non-disclosure of } \\
\text { information) }\end{array}$} & $04 / 07 / 07$ & Greenpeace criticises Vattenfall and authority for poor provision of information. \\
\hline & 05/07/07 & Supervisory authority criticises Vattenfall for poor provision of information. \\
\hline & $10 / 07 / 07$ & $\begin{array}{l}\text { Chancellor Merkel demands quick and proper investigation; Environment Minister Gabriel } \\
\text { accuses Vattenfall of hindering the inspection works. }\end{array}$ \\
\hline & $16 / 07 / 07$ & $\begin{array}{l}\text { Supervisory authority criticises communication processes at Krümmel; Bruno Thomauske, } \\
\text { Head of Vattenfall Europe Nuclear Energy, is dismissed and Johannes Altmeppen, Head of } \\
\text { Corporate Communication at Vattenfall Europe AG, resigns. }\end{array}$ \\
\hline & $18 / 07 / 07$ & $\begin{array}{l}\text { Head of Vattenfall Europe AG Klaus Rauscher resigns and is replaced by Hans Jürgen } \\
\text { Crammer }\end{array}$ \\
\hline & $27 / 07 / 07$ & Independent expert commission takes up investigation at Krümmel. \\
\hline & 07/08/07 & Start of Vattenfall Europe AG's dialogue campaign in major German newspapers. \\
\hline & $06 / 11 / 07$ & Independent expert commission publishes final report on investigation. \\
\hline & $31 / 12 / 07$ & End of period under observation; financial year end. \\
\hline
\end{tabular}

\subsection{Meso-level analysis}


The incident in the Krümmel power plant constitutes a legitimacy-threatening, unanticipated event. Due to the strong anti-nuclear sentiment in Germany, there is a climate of mutual mistrust between nuclear power companies and the German public. Vattenfall's management reacts to the legitimacy-threat posed by the incident by "provid[ing] as little information as possible, admit[ting] only what can no longer be denied and downplay[ing] the facts" (Bartsch et al., 2007). Management only issues a brief 'matter of fact' press release on the day of the incident (Vattenfall, 2007, 28 June) and waits three days to provide an account aimed at restoring legitimacy by means of portraying the fire as an isolated incident with no safety implications. It lends credence to its claim by quoting a statement issued by the regulatory authority, the Ministry of Social Affairs of Schleswig-Holstein, stating that the incident poses no danger to the population or the natural environment (Vattenfall, 2007, 1 July). Due to Vattenfall's prior poor track record regarding incidents and strong anti-nuclear sentiment in Germany, organisational audiences are antagonistic and have an incongruent view of the incident. Confronted with black smoke billowing out from the nuclear power plant, the incident at Krümmel sparks a fierce debate on the nuclear safety of all German nuclear power plants. The German news magazine Der Spiegel attributes the strong public reaction to the incident in Krümmel to its high visibility:

Whereas most of the 130 reactor incidents reported annually in Germany are minor and go unnoticed, smoke pouring out of a transformer as happened in Krümmel tends to attract attention" (Bartsch et al., 2007).

The incongruent interpretations of the incident by management and organisational audiences increase the conflict between Vattenfall and the public. The legitimacy crisis intensifies five days after the incident, on $3^{\text {rd }}$ July 2007, when the supervisory authority releases information relating to abnormalities during the shutdown of the plant (TAZ, 2007, July 4). As management failed to inform the public of these abnormalities in their initial account of the incident, the company faces severe criticism from politicians, environmental organisations, and the media. This results in Vattenfall experiencing two legitimacy threats, the first relating to the safety crisis involving a violation of performance standards (due to a technical problem resulting in the incident) and the second relating to the confidence crisis involving a violation of values (due to the nondisclosure of information) (see Figure 4). Vattenfall attempts to solve both crises by replacing the company executives responsible for nuclear safety and for corporate 
communication, namely Bruno Thomauske, Head of Vattenfall Europe Nuclear Energy, and Johannes Altmeppen, Vattenfall Europe AG's Head of Communication (Der Spiegel, 2007, 16 July). Executive replacement constitutes symbolic management in the form of dissociation. However, the reaction of Michael Müller, Germany's Minister of the Environment, suggests that organisational audiences see through Vattenfall's attempt to distance itself from both legitimacy-threatening events by putting the blame on individual members of the organisation:

That is the normal reaction, to sacrifice someone ... But this isn't just about switching personnel. ... Most important is reforming concepts. And in that regard I would like to hear a lot more from Vattenfall (Der Spiegel, 2007, 16 July).

The ensuing decline in public trust results in the loss of 250,000 customers in a six month period following the incident (Tagesspiegel, 2007, December 10).

\subsection{Micro-level analysis}

The statement issued by Klaus Rauscher, the CEO of Vattenfall Europe AG, during a press conference twelve days after the incident constitutes the first CEO account of the incident (document 1). The statement is characterised by technocratic discourse. Klaus Rauscher aims to restore organisational legitimacy by means of using facts and figures as a means of convincing organisational audiences of the insignificance of the incident. Despite being aware that Vattenfall faces two legitimacy threats, the first caused by the incident and involving the violation of performance standards and the second caused by management's inadequate disclosure and involving the violation of values, Klaus Rauscher nevertheless uses technocratic discourse which emphasises rationality, rather than emotion, to describe the incident and Vattenfall's responses to it.

The supervisory authority was informed in a prompt and comprehensive manner. This has been explicitly confirmed by the nuclear inspectorate. People inside the plant or in the proximity of the plant were not at risk at any point in time. This has also been confirmed by the supervisory authority. (document 1).

By emphasising fact and figures and rule compliance, his statement constitutes a reinforcement of management's initial account of the incident (see Figure 5). His use of technocratic discourse alienates the German public further, particularly powerful green and left-wing stakeholder groups, such as Greenpeace. What is more, Klaus Rauscher's depiction of the relationship between Vattenfall and organisational 
stakeholders as warring parties, with Vattenfall in the role of the victim and organisational audiences in the role of the aggressor, increases the conflict between Vattenfall and organisational audiences.

We are currently being attacked by people from a political persuasion who are against the peaceful use of nuclear energy. Opponents of nuclear energy are undoubtedly using the incidents in Brunsbüttel and Krümmel to their advantage. (document 1)

His statement provides an "unintentionally revealing picture" (Amernic and Craig, 2007 , p. 25) of Vattenfall's view of stakeholders as "threats ... to be dealt with in the same way as any other pressures" (O’Higgins, 2010, p. 163). The technocratic discourse used in his statement intensifies the crisis, resulting in his resignation eight days later (Der Spiegel, 2007, 18 July). This finding is in contrast to Elsbach's (2001) assumption that technical arguments communicated through technical jargon constitute the best way to restore legitimacy during unexpected legitimacy-threatening events.

Lars G. Josefsson, the CEO of the parent company Vattenfall AB, issues a statement on $18^{\text {th }}$ July 2007 in response to Klaus Rauscher's resignation in order to alleviate the crisis. He provides a negotiated account which takes organisational audiences' views into consideration (document 2). This is framed within the discourse of stakeholder engagement. Emphasising understanding and consideration, he aims to re-align Vattenfall's norms and values with that of society in order to restore the firm's badly damaged legitimacy.

A company restricting its disclosures to statement of a purely technical nature stressing the lack of safety implications of the incident has not taken its social responsibility seriously enough. Any organisation which runs highly technically complex operations such as nuclear power plants is not only accountable to the regulatory body, but also to the public whose trust and approval needs to be won means of dialogue. We have a special responsibility in this respect. (document 2)

Lars Josefsson frames his account as a 'new start'. He uses the discourse of stakeholder engagement as a means of constructing a "future desired image" (Abrahamsson et al., 2011) of the firm which is characterised by openness, transparency and dialogic communication with stakeholders. In fact, in his CEO message of the 2007 annual report he directly refers to the process of image construction when he says that '[we aim] to get our customers to perceive us as being a progressive, empathetic, easily accessible and reliable partner' (document 8). This entails changing Vattenfall's 
approach to corporate social responsibility by means of redefining organisational purpose, changing the way it identifies and manages its stakeholders, changing its performance metrics, and redefining the boundary between the organisation and its stakeholders. In stressing the tie between the German subsidiary and the Vattenfall Group Lars Josefsson attempts to transfer the slightly better image of the Group to its German subsidiary. This goes hand in hand with a dialogue campaign involving the placement of advertisements in German newspapers in order to demonstrate Vattenfall's willingness to engage in dialogue with organisational audiences.

Figure 5 outlines the interaction between Vattenfall's CEOs and organisational audiences during the process of reciprocal sense-making following the incident at Krümmel.

Figure 5: The negotiation of legitimacy between Vattenfall and its organisational audiences

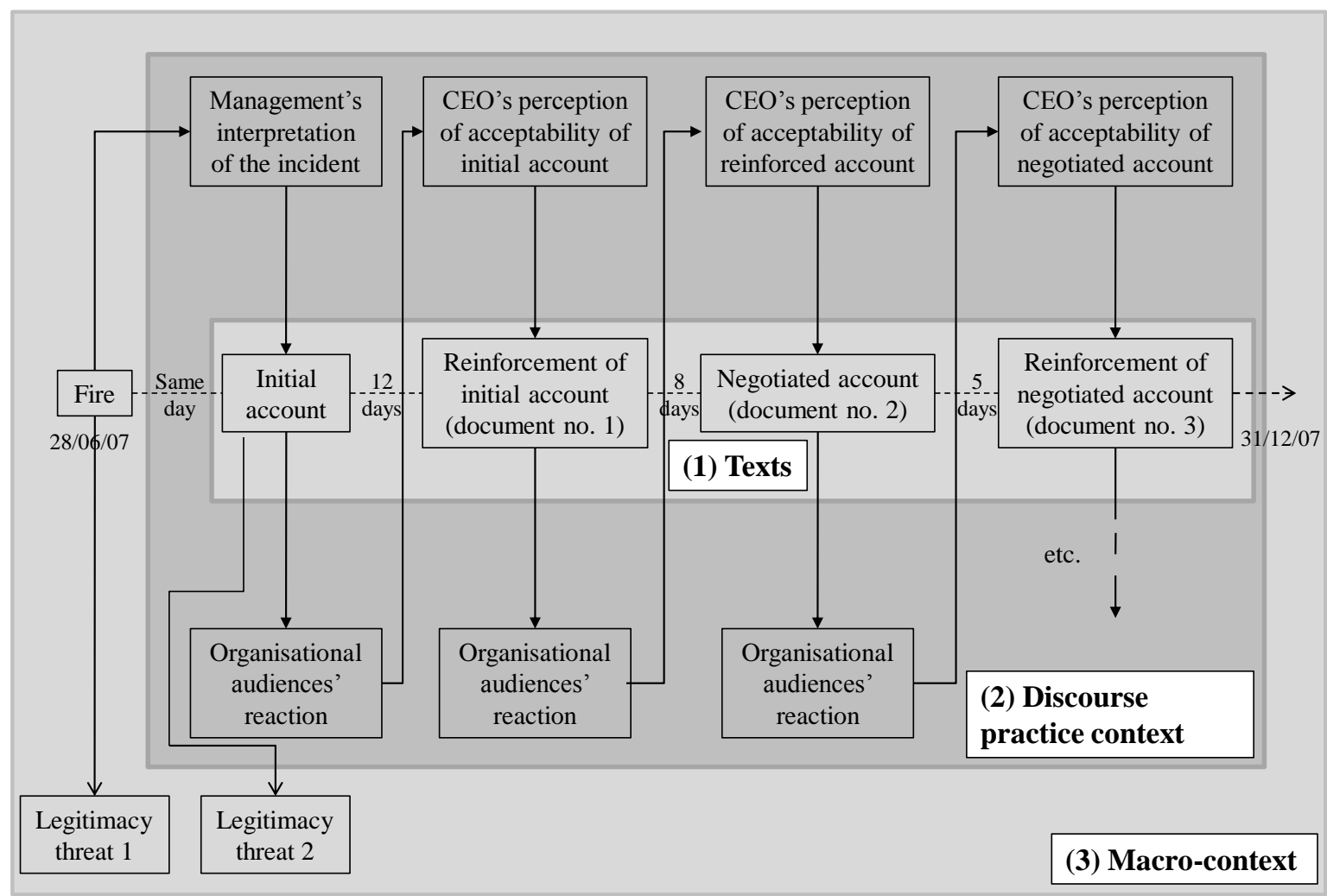

The eight CEO texts which constitute negotiated accounts of the incident (i.e., documents 2 to 9) are characterised by a high level of intertextuality, i.e., the presence of elements of other texts within a text (Fairclough, 2003). Intertextuality entails references to the same topic or event, either by reproducing the actual words or by 
providing a summary. This manifests itself by the recurrence of the same key words and metaphors (i.e., 'trust', 'dialogue', 'learning the language of the customers'). The high level of intertextuality in eight CEO texts over a six-month period suggests that the discourse of stakeholder engagement serves as a means of bringing Vattenfall's communication in line with institutional norms which stress openness, transparency, and corporate social responsibility.

Using the categories of text analysis developed in Section 3.4 we contrast the technocratic discourse used by Klaus Rauscher in his initial account of the incident with the discourse of stakeholder engagement used in subsequent CEO accounts. The discourses constitute opposing perspectives with respect to the organisation's stance towards its stakeholders (i.e., instrumental vs. normative) and manifest themselves in metaphors and binary opposites relating to the five aspects of corporate social responsibility identified by O'Higgins (2010), namely (1) organisational purpose, (2) stakeholder identification and salience, (3) stakeholder management, (4) performance metrics, and (5) the boundary between the organisation and its stakeholders. See Appendix 1 for an empirical illustration of the technocratic discourse and the discourse of stakeholder engagement in the nine CEO texts under investigation.

\section{(1) Organisational purpose (obligation vs. trust)}

In the initial account of the incident Klaus Rauscher regards information disclosure as a legal obligation towards the regulatory authority, rather than a duty to the general public. This is indicative of a sceptical stakeholder orientation characterised by a lack of recognition of stakeholders per se (O'Higgins, 2010). In subsequent accounts the organisational purpose is expanded to include a responsibility towards the public whose trust and confidence have to be gained by full information disclosure.

\section{(2) Stakeholder identification and salience (insiders vs. outsiders)}

In the initial account the relationship between the organisation and its environment is conceptualised as a dichotomy of insiders (including management and employees) and undifferentiated outsiders. Their relationship is characterised by mutual distrust and lack of understanding expressed by the metaphor of not having a common language. Information disclosure is kept to a bare minimum. In subsequent $\mathrm{CEO}$ accounts a wide range of stakeholders, including, customers, the general public, the media, and 
politicians are identified who management wants to engage in a dialogue.

\section{(3) Stakeholder management (confrontation vs. dialogue)}

Due to the strong anti-nuclear sentiments in Germany the public is portrayed as hostile in the initial account and treated as any other threat faced by the organisation (O'Higgins, 2010). Management regards organisational audiences' interpretations of the incident to be biased and drafts in external experts 'in order to render the debate more neutral and objective' (document 1). The creation of monitors and watchdogs constitutes symbolic management in the form of strategic restructuring.

The use of metaphor, particularly during a crisis, "signals strong and nuanced leadership" (Amernic and Craig, 2007, p. 29). However, the opposite is also true. Klaus Rauscher's ill-judged choice of the metaphor of warfare ('enemies', 'attack', 'bunker'), persecution ('witch hunt', 'victim'), alienates the public to such an extent that the organisation's legitimacy is further damaged. It results in a series of executive replacements in Vattenfall's German subsidiary (including Klaus Rauscher's own resignation). In subsequent accounts Vattenfall's initial lack of understanding of stakeholder views and expectations is expressed by means of the metaphor of language learning ('to know and to understand what is the language of our customers' [sic!], document 6). In the initial account the outside world is portrayed as hostile which results in Vattenfall sealing itself off from outside influences and management and employees adopting a 'certain bunker mentality' (document 3). This results in releasing "as little information as possible, admit[ting] only what can no longer be denied and downplay[ing] the facts" (Bartsch et al., 2007). The 'new start' (document 2) is characterised by redefining stakeholders as partners, rather than enemies. This entails reconstructing the boundary between the organisation and society as permeable, with organisational constituents and information moving freely between the organisation and its environment ('we become more present as management outside', document 6).

\section{(4) Performance metrics (correctness vs. understanding)}

The initial account is characterised by instrumental rationality. Focusing on technical issues relating to the incident and emphasising procedures and protocols, it emphasises action based on reason and fact. By contrast, subsequent accounts are characterised by substantive rationality. Vattenfall's attempt to empathise with stakeholders in order to 
gain public trust it promotes action based on empathy, emotion, and dialogue.

\section{(5) Boundary between organisation and stakeholders (closed vs. open)}

In the initial account Klaus Rauscher constructs Vattenfall as separate from society. This manifests itself in the use of the binary opposites of 'inside' and 'outside'. Management and employees are regarded as located inside the organisation and stakeholders, the public and the media, as located outside the organisation. This results in the view of stakeholders as not having any intrinsic right to information. In the initial account Vattenfall is portrayed as hermetically sealed off from its environment ('bunker mentality', document 3). Subsequent accounts are characterised by the metaphor of a physical barrier between the organisation and its environment which management needs to 'break through' (document 3 ) by means of 'hold[ing] open houses' (document 3 ) and by 'transparent information and good communication' (document 9).

\subsection{Discussion}

The confidence crisis following the initial misjudgement of the situation forces Vattenfall to redefine its relationship with its stakeholders in order to restore its badly damaged legitimacy. For this purpose, Vattenfall's CEOs provide a negotiated account which takes organisational audiences' views into consideration (documents 2 to 9 ). This is framed within the discourse of stakeholder engagement. Emphasising understanding and consideration, management aims to re-align Vattenfall's norms and values with that of society in order to restore the firm's badly damaged legitimacy. Depending on whether this is accompanied by any real changes in organisational practices and values or entails merely a manipulation of audience perceptions of practices and values, this either constitutes substantive or symbolic management. What is more, the eight CEO texts constituting subsequent accounts of the indecent (documents 2 to 9) are characterised by a high level of intertextuality. This suggests that management uses the discourse of stakeholder engagement to bring Vattenfall's communication in line with institutional norms which are characterised by openness, transparency, and corporate social responsibility. In the same vein, depending on whether this is accompanied by a change in organisational structures and processes or merely by a mere manipulation of audience perceptions of these structures and processes, this constitutes either isomorphism or decoupling. 
Evidence from the micro-level analysis and the discourse practice context suggests that Vattenfall's CEOs strategically use the discourse of stakeholder engagement to persuade organisational audiences that Vattenfall has changed its stance towards its stakeholders. Lars G. Josefsson's statement in relation to Vattenfall's interim results suggests that Vattenfall's professed stakeholder engagement is more about achieving 'a turn around in public image' (document 4), rather than a real change in values. The contradiction between espoused and actual values is also evident in Lars G. Josefsson's statement relating to Klaus Rauscher's resignation (document 2) Lars G. Josefsson's mixes the discourse of stakeholder engagement with the discourse of economics: 'We represent the values of effectiveness, responsibility and, most importantly, openness' (emphasis added by authors). In the same statement he claims that 'Vattenfall wants to be a company which "understands their [customers'] concerns", and which is their "first choice amongst all its competitors" (emphasis added by authors). What is more, in the CEO's message of Vattenfall's 2007 annual report (document 8) Lars G. Josefsson uses an accounting metaphor ('our most precious asset') in relation to 'trust'. This suggests that Vattenfall's CEOs adopt an ad hoc normative attitude to stakeholders (O'Higgins, 2010) for public relations and placatory reasons to resolve the conflict between the organisation and its audiences following the incident at Krümmel. Thus, the discourse of stakeholder engagement serves as a means of signalling a change in stakeholder orientation, yet maintaining the status quo. The high level of intertextuality in the eight subsequent CEO accounts of the incident suggests that the discourse of stakeholder engagement becomes institutionalised during the six-month period of observation, yet evidence from our micro-level analysis and from the discourse practice context suggests that the emphasis on openness, transparency, and corporate social responsibility, is decoupled from actual organisational values and practices. This suggests that Vattenfall's CEOs strategically use discourse to manufacture organisational audiences' consent regarding the continued operation of the Krümmel power plant and the deceleration of the nuclear phase out in Germany.

What is more, the dialogue campaign in German newspapers following the incident in Krümmel constitutes a temporary ad hoc project (symbolic management), rather than a genuine change in organisational practices (substantive management), as "the left half of the ads presented the number of a special service hotline, the right half was made up of frequently asked questions concerning the ecological responsibility of the 
corporation. The questions were both asked and answered by the corporation" (Schultz and Wehmeier, 2010, p. 19). Vattenfall uses a similar monologic strategy in its 2007 Corporate Social Responsibility Report where the newly appointed Chief Nuclear Officer Per-Olof Waessman is 'interviewed' by Vattenfall. This means Vattenfall has control over both questions and answers. The dialogue campaign can therefore be regarded as a mere "placation and co-optation" (O’Higgins, 2010, p. 163) mechanism. What is more, it is primarily directed at customers by whom Vattenfall wants to be perceived as 'a progressive, empathetic, easily accessible and reliable partner' (document 8). Greenpeace, a key stakeholder, is excluded from dialogue. This is probably due to Vattenfall's perception of Greenpeace as too hostile to be placated. Greenpeace exposes Vattenfall's discourse of corporate social responsibility as greenwash on its website by means of a so-called 'Schwarzbuch' (literally, 'black book'). "By issuing misleading reports and pseudo-initiatives regarding climate change the firm attempt to hoodwink the public" (Greenpeace).

Our findings support O'Higgins' (2010) argument that organisations with an instrumental stakeholder orientation tend to resolve conflicts of interest between the organisation and its audiences by resorting to impression management, rather than instigating real changes. It would be interesting to explore how an organisation with a normative stakeholder orientation responds to a legitimacy threat. We would expect management to adopt a discourse of stakeholder engagement accompanied by a twoway dialogue with organisational audiences and real changes in organisational practices and values (O'Higgins, 2010). This opens up possibilities for future research, possibly in the form of two-case study or multi-case study research based on organisations with contrasting stakeholder orientations.

There are two limitations to the study. First, we focus on a relatively short period of time. Only a longitudinal study in the vein of Mäkelä and Laine (2011), who analyse the corporate reporting practices of a Finnish company over a nine-year period, would be able to establish whether the change in discourse resulting from external pressures exerted upon Vattenfall by antagonistic organisational audiences in the aftermath of the incident becomes institutionalised. Second, as the main focus of our analysis is on CEO texts, we do not know whether and how organisational audiences responded to the change in discourse (apart from Greenpeace whose reaction is discussed in Section 5.4). 
Only a detailed analysis of newspaper articles in the vein of Breton and Coté (20060 and Aerts and Cormier (2009) would be able to establish whether stakeholders accepted Vattenfall's reality construction and were indeed placated by it.

\section{SUMMARY AND CONCLUSION}

In our analysis of managerial discourse after a legitimacy-threatening incident in a nuclear power plant in Germany we find that CEOs switch from technocratic discourse to a discourse of stakeholder engagement to resolve a conflict between the organisation and its audiences. Management uses the discourse of stakeholder engagement to signal a change in its stance towards its stakeholders. However, evidence from the micro-level analysis and the discourse practice context indicates that this change in discourse does not go hand in hand with changes in values and organisational practices and thus constitutes symbolic, rather than substantive management. We find that discourse in corporate communication is used as a means of placating antagonistic organisational audiences and manufacturing their consent. The use of discourse as a means of constructing reality in a way that benefits the company at the expense of society is an ethical issue, as it sustains relations of domination. Our findings thus contribute to the critical corporate communication literature which regards corporate narrative reporting as a means of consolidating the private interests of corporations, rather than increasing transparency and accountability (e.g., Cho, 2009; Mäkelä and Laine, 2011; MerklDavies and Koller, 2011). What is more, our findings indicate that CEOs put forward an account of events that serves their ends, rather than being accountable to organisational stakeholders and to society. However, if CEOs are myopically focused on furthering their own ends and are encouraged to do so by 'yes-men', they may put the company at risk. 


\section{References}

Abrahamsson, G, H. Englund and J. Gerdin: 2011, 'Organisational identity and management accounting change', Accounting, Auditing, and Accountability Journal 24(3), 345-376.

Aerts, W. and D. Cormier: 2009, 'Media Legitimacy and Corporate Environmental Communication', Accounting, Organizations and Society 34(1), 1-27.

Amernic, J. H. and R. J. Craig: 2006, CEO Speak: The Language of Corporate Leadership, McGill-Queen's University Press.

Amernic, J. H. and R. J. Craig: 2007, 'Guidelines for CEO-speak: Editing the Language of Corporate Leadership', Strategy and Leadership 35(3), 25-31.

Arndt, M. and B. Bigelow: 2000, 'Presenting Structural Innovation in an Institutional Environment: Hospital's Use of Impression Management', Administrative Science Quarterly 45(3), 494-522.

Ashforth, B. E. and B. W. Gibbs: 1990, 'The Double-edge of Organizational Legitimation', Organization Science 1(2), 177-194.

Bartsch, M., F. Dohmen, S. Kaiser, S. Knauer, U. Ludwig, C. Meyer and R. Nelles: 2007, German Mishaps Put Nuclear Power under Scrutiny', Spiegel Online. http://www.spiegel.de/international/germany/0,1518,494707,00.html.

Berliner Zeitung: 2007, June 30, 'Brandheiße Alternativen', http://www.berlinonline.de/berlinerzeitung/spezial/dossiers/klimawandel/81066/index.php.

Berrone, P., L. Gelabert and A. Fosfuri: 2009, 'The Impact of Symbolic and Substantive Actions on Environmental Legitimacy', Working Paper.

Borglin, O., G. Lindell and S. Lindström: 2008, 'Isomorphic Learning at a Disciplined Nuclear Power Plant', Bachelor Thesis, School of Business Economics and Law, Göteborg University, http://gupea.ub.gu.se/bitstream/2077/17870/1/gupea_2077_17870_1.pdf.

Brennan, N. M. and J. P. Conroy: 2010, 'Executive Hubris: The Case of a Bank CEO', Working Paper.

Breton, G. and L. Coté: 2006, 'Profit and the Legitimacy of the Canadian Banking Industry', Accounting, Auditing and Accountability Journal 19(2), 512-539.

Bundesministerium für Umwelt, Naturschutz und Reaktorsicherheit: 2006, 'Große Mehrheit der Bevölkerung für Beibehaltung des Atomausstiegs', http://www.bmu.de/atomenergie_sicherheit/downloads/doc/37879.php. 
Cho, C.H.: 2009, 'Legitimation strategies used in response to environmental disaster: A French case study of Total SA's Erika and AZF incidents', European Accounting Review 18(1), 33-62.

Collins, J.: 2001, Good to Great: Why Some Companies Make the Leap... and Others Don't (HarperCollins Publishers Inc, New York, NY).

Craig, R. J. and J. H. Amernic: 2004a, 'The Deployment of Accounting-related Rhetoric in the Prelude to Privatization', Accounting, Auditing and Accountability Journal 17(1), 41-58.

Craig, R. J. and J. H. Amernic: 2004b, 'Enron Discourse: the Rhetoric of a Resilient Capitalism', Critical Perspectives on Accounting 15(6/7), 813-851.

Craig, R. J. and J. H. Amernic: 2006, 'The Mobilization of Accounting in Preening for Privatization', Accounting, Auditing and Accountability Journal 19(1), 82-95.

Craig, R. J. and J. H. Amernic: 2008, 'A Privatization Success Story: Accounting and Narrative Expression over time', Accounting, Auditing and Accountability Journal 21(8), 1085-1115.

Crowther, D., C. Carter and S. Cooper: 2006, 'The poetics of corporate reporting: Evidence from the UK water industry', Critical Perspectives on Accounting 17(1/2), 175-201.

Der Spiegel: 2007, July 16, 'Energy Giant Fires Nuclear Boss', http://www.spiegel.de/international/germany/0,1518,494734,00.html.

Der Spiegel: 2007, July 18, 'The Fallout continues: Vattenfall Europe Boss Rauscher Resigns', http://www.spiegel.de/international/business/0,1518,495264,00.html.

Der Spiegel: 2010, September 13, 'Laufzeitverlängerung im September 2010 beschlossen', http://www.spiegel.de/spiegel/print/d-73791883.html.

Deutsche Welle. http://www.dw-world.de/dw/article/0,2144,2306337,00.html.

Die Welt: 2007, July 2, 'Streit über Wiederanfahren von Brunsbüttel', http://www.welt.de/welt print/article990186/Streit ueber Wiederanfahren von Brunsbuettel.html.

DiMaggio, P. J. and W. Powell: 1983, 'The Iron Cage Revisited: Institutional Isomorphism and Collective Rationality in Organizational Fields', American Sociological Review 48, 147-60.

Dowling, J. and J. Pfeffer: 1975, 'Organizational Legitimacy: Social Values and Organizational Behavior', Pacific Sociological Review 18, 122-136. 
Elsbach, K.D.: 1994, 'Managing organizational legitimacy in the Californian cattle industry: the construction and effectiveness of verbal accounts', Administrative Science Quarterly, 39(1), 57-88.

Elsbach, K. D.: 2001, 'The Architecture of legitimacy: Constructing accounts of organisational controversies', in J. T. Jost and B. Major (eds.), The Psychology of Legitimacy (Cambridge University Press, Cambridge), 391-415.

Fairclough, N.: 1992, Discourse and social change (Polity Press, Oxford).

Fairclough, N.: 1993, 'Critical Discourse Analysis and the Commodification of Public Discourse', Discourse and Society 4(2), 133-168.

Fairclough, N.: 1995, Critical Discourse Analysis: The Critical Study of Language (Longman, London).

Fairclough, N.: 2003, Analysing Discourse: Text Analysis for Social Research (Routledge, London).

Fairclough, N.: 2009, 'A Dialectical-Relational Approach', in R. Wodak and M. Meyer (Eds.), Methods for Critical Discourse Analysis. $2^{\text {nd }}$ ed. London: Sage.

General-Anzeiger: 2007, June 30, 'Debatte über Sicherheit; ENERGIE: Pannen in Kernkraftwerken geben Rätsel auf".

Ginzel, L. E., R. M. Kramer and R. I. Sutton: 2004, 'Organizational Impression Management as a Reciprocal Influence Process: the Neglected Role of the Organisational Audience', in M. J. Hatch and M. Schultz (eds.), Organizational Identity (Oxford University Press), 223-261.

Goffman, E.: 1959, The Presentation of Self in Everyday Life (Doubleday Anchor Books, New York).

Goffman, E.: 1981, Forms of talk. (University of Pennsylvania Press, Philadelphia).

Greenwood, M.: 2007, 'Stakeholder Engagement: Beyond the myth of Corporate Responsibility', Journal of Business Ethics 74(4), 315-327.

Hatch, M. J. and A. L. Cunliffe: 2006, Organisation Theory: Modern, Symbolic, and Postmodern Perspectives, 2nd edition (Oxford University Press, Oxford).

Hooghiemstra, R.: 2000, 'Corporate Communication and Impression Management New Perspectives Why Companies Engage in Corporate Social Reporting', Journal of Business Ethics 27(1-2), 55-68.

Hyland, K.: 1998, 'Exploring Corporate Rhetoric: Metadiscourse in the CEO's Letter', The Journal of Business Communication 35(2), 224-245. 
Lakoff, G. and M. Johnson: 1980, Metaphors we Live By (University of Chicago Press, Chicago).

Lightstone, K. and C. Driscoll: 2008, 'Disclosing Elements of Disclosure: A Test of Legitimacy Theory and Company Ethics', Canadian Journal of Administrative Sciences 25(1), 7-21.

Lindblom, C. K.: 1994, 'The Implications of Organizational Legitimacy for Corporate

Social Performance and Disclosure', Critical Perspectives on Accounting Conference, New York.

Linsley, P. and P. Kajüter: 2008, 'Restoring and Repairing Legitimacy: a Case Study of Impression Management in Response to a Major Risk Event at Allied Irish Banks plc', International Journal of Financial Services Management 3(1), 65-82. Livesey, S. M.: 2002a, 'Global Warming Wars: Rhetorical and Discourse Analytical Approaches to Exxon Mobile's Corporate Public Disclosure', Journal of Business Communication 39(1), 117-146.

Livesey, S. M.: 2002b, 'Transparent and Caring Corporations? A Study of Sustainability Reporting by The Body Shop and Royal Dutch/Shell', Organization and Environment 15(3), 233-258.

Llewellyn, S.: 1999, 'Narratives in Accounting and Management Research', Accounting, Auditing and Accountability Journal 12(2), 220-236.

Mäkelä, H. and M. Laine: 2011, 'A CEO with many messages: Comparing the ideological representations provided by different corporate reports', Accounting Forum, forthcoming.

McKenna, D. J. and P. Graham: 2000, ‘Technocratic discourse: A primer', Journal of Technical Writing and Communication 30(3), 219-247.

Merkl-Davies, D. M. and N. M. Brennan: 2011, 'A Conceptual Framework of Impression Management: New insights from Psychology, Sociology, and Critical Perspectives', Accounting and Business Research, forthcoming.

Merkl-Davies, D. M and V. Koller: 2011, 'Metaphoring people out of this world: A Critical Discourse Analysis of a chairman's statement of a UK defence firm', Accounting Forum, forthcoming.

Milne, M. Tregidga, H. and S. Walton: 2009, 'Words not action! The ideological role of sustainable development reporting', Accounting, Auditing, and Accountability Journal 22(8), 1211-1257. 
Ogden, S. and J. Clarke: 2005, 'Customer Disclosure, Impression Management and the Construction of Legitimacy: Corporate Reports in the UK Privatised Water Industry', Accounting, Auditing and Accountability Journal 18(3), 313-345.

O’Higgins, E. R. E.: 2010, 'Corporations, Civil Society, and Stakeholders: An Organisational Conceptualization', Journal of Business Ethics 94(2), 157-176.

O'Keefe, P. and S. Conway: 2008, 'Impression Management and Legitimacy in a NGO Environment', University of Tasmania School of Accounting Working Paper Series 02/2008.

Palazzo, G. and A.G. Scherer: 2006, 'Corporate Legitimacy as Deliberation: A Communicative Framework', Journal of Business Ethics 66(1), 71-88.

Roose, J.: 2010, 'Der endlose Streit um die Atomenergie. Konfliktsoziologische Untersuchung einer dauerhaften Auseinandersetzung', in P. H. Feindt and T. Saretzki (eds.), Umwelt- und Technikkonflikte (Vs Verlag, Wiesbaden).

Schlenker, B. R.: 1980, Impression Management: The Self-Concept, Social Identity, and Interpersonal Relations (Brooks/Cole, Monterey).

Schultz, F. and S. Wehmeier: 2010, 'Institutionalisation of Corporate Social Responsibility within Corporate Communications: Combining Institutional, Sensemaking and Communication Perspectives', Corporate Communications: An International Journal 15(1), 9-29.

Schwarzbuch Vattenfall. http://www.klimaunterschriftvattenfall.de/files/Vattenfall_Schwarzbuch_1228148011.pdf.

Stoett, P.: 2003, 'Toward Renewed Legitimacy? Nuclear Power, Global Warming, and Security', Global Environmental Politics 3(1), 99-116.

Suchman, M. C.: 1995, 'Managing Legitimacy: Strategic and Institutional Approaches', Academy of Management Research 20(3), 571-610.

Tagesspiegel: 2008, December 10, 'Vattenfall verliert 250000 Kunden', http://www.tagesspiegel.de/wirtschaft/unternehmen/vattenfall-verliert-250-000kunden/1118412.html.

TAZ: 2007, July 4, 'Vattenfall vertuscht Atomunfall', http://www.taz.de/?id=475andart=1498andno cache=1.

Tomer, J.: 2008, 'Beyond the rationality of economic man: toward the true rationality of human man', Journal of Socio-Economics, 37(5), 1703-1712.

Tregidga, H., M. Milne, M. and K. Kearins: 2007, 'Organisational Legitimacy in Bridging the Text and Context of Social and Environmental Reporting', Working 
paper.

http://www.acis.canterbury.ac.nz/documents/Markus_Milne_Research_Program mes/Organisational_Legitimacy_and_SER.pdf.

van Dijk, T. A.: 2003, 'Critical Discourse Analysis', in D. Schiffrin, D. Tannen, and H. H. Hamilton (Eds.), The Handbook of Discourse Analysis (Wiley-Blackwell, Malden and Oxford).

Vattenfall: 2007, June, 28, 'Kernkraftwerke Brunsbüttel und Krümmel vom Netz', http://www.vattenfall.de/www/vf/vf_de/225583xberx/232127press/232157press/ $232187 \mathrm{archi} / 258228 \mathrm{press} /$ index.jsp?pmid=112839.

Vattenfall: 2007, July, 1, 'Kernkraftwek Brunsbüttel wieder am Netz', http://www.vattenfall.de/www/vf/vf_de/225583xberx/232127press/232157press/ 232187archi/258228press/index.jsp?pmid=112894.

Weber, M.: 1968, Economy and Society. 3 Volumes (Bedminster Press, Towata).

Wodak, R. and M. Meyer: 2009, 'Critical discourse analysis: history, agenda, theory and methodology', in R. Wodak, R. and M. Meyer (Eds.), Methods for Critical Discourse Analysis ( $2^{\text {nd }}$ edition, Sage, London). 
Appendix 1 illustrates our text analysis approach by means of quotes from the nine

CEO texts. For each area the left-hand column represents the instrumental dimension of stakeholder orientation and the right-hand column the normative dimension of stakeholder orientation.

Appendix 1: Contrasting technocratic discourse and the discourse of stakeholder engagement in Vattenfall's CEO texts

(1) Organisational purpose

Regulatory body (Obligation)

- "Clearly, immediate and extensive information was submitted to the authorities" (document 4)

- "But it's also correct that we consistently complied with our obligation to notify the authorities." (document 3)

\section{Stakeholders (Trust)}

- "Ensuring that the general public feel safe and trust our ability to provide power" (Document 9)

- "Rebuilding confidence in Germany" (document 4)

- "Ensuring that the general public feel safe and trust our ability to provide power" (Document 9)

- "This lack of confidence on part of the public, customers and other stakeholders is to some extent our own fault" (document 4)

- "We must put more emphasis into the dialogue with employees, customers and other stakeholders to develop trust and confidence" (document 4)

- "Our main priorities are operative safety and the building of trust and confidence" (document 7)

- "Our responsibility is not limited to safe operation, but also trying to answer ... questions [from the public]. It's part of our effort to be a good corporate citizen. The public expects continuous and comprehensive information, transparency, honesty and openness" (document 9)

- "We want and have to restore the lost trust in Vattenfall Europe as an organisation “ (document 5)

- "Power companies only earn public acceptance, if they can demonstrate that their activities serve the public good" (document 2)

- "And we have then brought into place a 'restore trust campaign'. And this is we have to work on our main objectives that we restore lost credibility and trust as an important basis for our business success" (document 6)

- $\quad$ "It is our responsibility alone to win public trust in our nuclear power plants" (document 2) 
- “A company restricting its disclosures to statement of a purely technical nature stressing the lack of safety implications of the incident has not taken its social responsibility seriously enough. Any organisation which runs highly technically complex operations such as nuclear power plants is not only accountable to the regulatory body, but also to the public whose trust and approval needs to be won means of dialogue." We have a special responsibility in this respect" (document 2)

- "The demands on us as an energy company can be summarised with the words Safety and Trust" (document 8)

- "Trust, in turn, is our most precious asset" (document 8)

- "Trust must also be the foundation of our aspirations to get our customers to perceive us as being a progressive, empathetic, easily accessible and reliable partner" (document 8)

(2) Stakeholder identification and salience

\section{Bunker (Insiders)}

- "Employees at nuclear power plants often don't understand other people, while outsiders don't understand nuclear energy." (document 3)

- $\quad$ "Our employees are not afraid of nuclear power, but sometimes they are afraid of the outside world. Many believe that people out there are their enemies and that anything they say will only be used against them." (document 3)

- $\quad$ "We created an open-book policy with all of our stakeholders so they get direct access to our information and we become more present as management outside" (document 6)

(3) Stakeholder management Enemy (Confrontation)

\section{Outside world( Outsiders)}

- "Employees at nuclear power plants often don't understand other people, while outsiders don't understand nuclear energy." (document 3)

- "Our employees are not afraid of nuclear power, but sometimes they are afraid of the outside world. Many believe that people out there are their enemies and that anything they say will only be used against them." (document 3)

- "We created an open-book policy with all of our stakeholders so they get direct access to our information and we become more present as management outside" (document 6)

- "So we made an active dialogue with public, media and politicians" (document 6)

- "Our problem was our inability to communicate this to the public" (documents 9)

- "Ensuring that the general public feel safe and trust our ability to provide power" (documents 9)

- "We must put more emphasis into the dialogue with employees, customers and other stakeholders to develop trust and confidence" (document 4)

- "This lack of confidence on part of the public, customers and other stakeholders is to some extent our own fault" (document 4) 
- “Our employees are not afraid of nuclear power, but sometimes they are afraid of the outside world. Many believe that people out there are their enemies and that anything they say will only be used against them" (document 3)

- "Yes, there is a certain bunker mentality." (document 3)

- "We are currently being attacked by people from a political persuasion who are against the peaceful use of nuclear energy.

Opponents of nuclear energy are undoubtedly using the incidents in Brunsbüttel and Krümmel to their advantage." (document 1))

- "Our employees are not afraid of nuclear power, but sometimes they are afraid of the outside world. Many believe that people out there are their enemies and that anything they say will only be used against them" (document 3)

- $\quad$ "However we cannot solely see ourselves as victims of a campaign against nuclear power" (document 1)

- "I refuse to participate in a witch hunt initiated in political circles, especially not against any of my colleagues in the nuclear power plants" (document 1)

(4) Performance metrics

Facts (Correctness)

- "The rapid shutdown was carried out properly and correctly" (document 1)

- $\quad$ "Both incidents were classified as 0 (zero) on the international, seven-point INESscale, i.e. as incidents of 'no safety significance'. The emergency shutdowns were carried out correctly" (document 1)

- "Incidents are classified according to an international scale. This scale ranges from zero to seven. The fire at Krümmel was in category "zero," which means that it was insignificant or of only minor significance in terms of safety." (document 3)

- "But it's also correct that we consistently complied with our obligation to notify the authorities." (document 3)

- "A safety culture entails the responsible handling of facts and evaluations" (document 1)
- “A company restricting its disclosures to statement of a purely technical nature stressing the lack of safety implications of the incident has not taken its social responsibility seriously enough. Any organisation which runs highly technically complex operations such as nuclear power plants is not only accountable to the regulatory body, but also to the public whose trust and approval needs to be won means of dialogue." We have a special responsibility in this respect" (document 2)

- "So we made an active dialogue with public, media and politicians" (document 6)

- "We must put more emphasis into the dialogue with employees, customers and other stakeholders to develop trust and confidence" (document 4)

- "Our problem was our inability to communicate this to the public" (documents 9)

- "We must make sure that we provide transparent information and good communication" (document 9)

\section{Feeling (Understanding)}

- "Ensuring that the general public feel safe and trust our ability to provide power" (Document 9)

- "Questions arise that sometimes lead to fears" (document 9)

- "I also understand people's fears" (document 3)

- "I am particularly saddened that we have disappointed a lot of customers in our loyal markets in Hamburg and Berlin" (document 3) 
- "Take a look at the facts." (document 3)

- "The events ... were from a technical perspective minor ... Both events were classified as a zero in the seven degree International Nuclear Event Scale (INES), i.e. deviations with 'no safety significance': (document 9)

- "The safety system following the scrams at the nuclear power plants worked properly" (document 9)

- "I am going to employ external experts as personal advisors... in order to render the public debate more neutral and objective" (document 1)

\section{(5) Boundary between organisation and environment}

\section{Closed}

- "Our employees are not afraid of nuclear power, but sometimes they are afraid of the outside world. Many believe that people out there are their enemies and that anything they say will only be used against them" (document 3)

\section{Open}

- "We created an open-book policy with all of our stakeholders so they get direct access to our information and we become more present as management outside" (document 6)

- "Employees at nuclear power plants often don't understand other people, while outsiders don't understand nuclear energy. Of course, in this sort of psychological situation management bears a special responsibility to break through this mentality and establish a culture of openness" (document 3)

- "We will pursue a public information policy of openness and transparency in the future. For example, we plan to hold open houses at our power plants" (document 3)

- "We represent the values of effectives, responsibility and, most importantly, openness" (document 2)

- "We must make sure that we provide transparent information and good communication" (document 9) 